\title{
PRAWA CZŁOWIEKA - \\ RELIGIA OBYWATELSKA ZACHODU. PERSPEKTYWA EUROPEJSKIEJ NOWEJ PRAWICY
}

\author{
HUMAN RIGHTS - CIVIC RELIGION OF THE WEST: \\ PERSPECTIVE OF THE EUROPEAN NEW RIGHT
}

Paweł Bielawski* (1)

\begin{abstract}
- ABSTRAKT
Tematem artykułu są prawa człowieka w perspektywie Europejskiej Nowej Prawicy (ENP). Alain de Benoist (główny ideolog) uważa, że prawa człowieka stały się religią obywatelską Zachodu, która zastąpiła chrześcijaństwo w zlaicyzowanej przestrzeni publicznej, stając się głównym, ideologicznych punktem odniesienia Zachodu. Artykuł omawia chrześcijańską genezę praw człowieka i krytykę praw człowieka z punktu widzenia ENP. A. de Benoist argumentuje, iż prawa człowieka są de facto bronią ideologiczną Zachodu, służącą do symbolicznego zdominowania niezachodnich państw.
\end{abstract}

Słowa kluczowe: prawa człowieka; religia; chrześcijaństwo; nowa prawica; GRECE
The topic of the article are human rights in the perspective of the European New Right (ENR). Alain de Benoist (main ideologist of the movement) thinks that human rights became the civic religion of the West that replaced Christianity in the public sphere, becoming the main ideological reference point of the West. The article outlines the Christian genesis of human rights and the critique of human rights, from the standpoint of ENR ideology. Alain de Benoist argues that human rights are in fact an ideological weapon of the West whose aim is to dominate non-Western countries through symbolic power.

Keywords: human rights; religion; Christianity; new right; GRECE

* Uniwersytet Jagielloński, Wydział Filozoficzny. 


\section{WSTĘP}

Europejska Nowa Prawica (Nouvelle Droite, ENP) to współczesny nurt intelektualny, metapolityczny, powstały we Francji pod koniec lat 60., który odcisnął wyraźne piętno na zachodniej scenie ideowo-politycznej. Krytycznie odnosząc się zarówno do tradycji chrześcijańskiej, jak i oświeceniowej, próbuje stworzyć nową syntezę ideologiczną, opierając się, w ich mniemaniu, na spuściźnie „indo-europejskiej". Istnieje oficjalnie od 1968 r., w którym to powołany został do życia think-tank GRECE (Groupement de recherche et d'études pour la civilisation européene) (Taguieff, 1994). Główną postacią i ideologiem nurtu jest Alain de Benoist - publicysta i myśliciel polityczny, jak również autor wielu książek, m.in. Au-delà des droits de l'homme: pour défendre les libertés (2004). ENP nie doczekała się jeszcze w języku polskim żadnego, syntetycznego opracowania naukowego.

Lider ruchu ENP stawia tezę, że prawa człowieka pojmowane jako ideologia stały się swoistą religią obywatelską Zachodu, zajmując miejsce chrześcijaństwa w zlaicyzowanej przestrzeni publicznej. Zajmuje wobec nich sceptyczne stanowisko. Uważa on, że prawa człowieka nie mają wcale charakteru uniwersalnego, są natomiast zakamuflowaną formą zachodniego imperializmu i - niezależnie od szlachetnych intencji - stały się bronią ideologiczną silnych państw przeciwko słabszym państwom, które nie chcą podporządkować się tym pierwszym, czego przykładem mogą być inwazje na Irak czy Libię. Ponadto uważa on, że prawa człowieka w sposób nieuchronny prowadzą do konfliktu z prawami wspólnot, tj. do praw tradycyjnych kultur do zachowania swojej odrębności i integralności. Dziś - wg francuskiego autora - Zachód zdaje się zapominać o tym, że kultury występują w mnogości. Wszystkie „przelewane są przez sito” jednakowego, zachodniego modelu rozwoju i modernizacji. Za ideologią praw człowieka kryć się ma „niewiarygodna pogarda” dla praw ludów do samodzielnego decydowania o swoim losie. W imię wiecznej teraźniejszości (proweniencji globalistyczno-rynkowej) wymazywana ma być przeszłość ludów, które - pozbawiane swej przeszłości - redukowane są li tylko do gatunku (Benoist, Faye, 1981).

Istnieje, niewątpliwie, zoologiczna jedność rodzaju ludzkiego - jednak wyłącznie na poziomie biologicznym. W perspektywie ENP nie można definiować człowieka wyłącznie poprzez jego cechy biologiczne. Wręcz odwrotnie - to, co specyficznie ludzkie, to, co określa człowieka jako człowieka, wynikać ma z kultury i historii (Benoist, Faye, 1981). Człowiek to nie tylko zwierzę - nie można określić jego specyficzności wyłącznie poprzez przynależność do gatunku. Jak podkreśla A. de Benoist, jest jedynym ze wszystkich zwierząt, który nie jest 
zdeterminowany przez swoją przynależność do gatunku. „Człowiek jest bytem kulturowym. Innymi słowy, nie ma paradygmatu wspólnego dla całej ludzkości. Historycznie rzecz ujmując, kultury krystalizują się zawsze w liczbie mnogiej" (Benoist, Faye, 1981).Zdaniem francuskiego myśliciela absolutyzacja oderwanej jednostki prowadzi do rozrywania tkanki społecznej, jaką jest właśnie specyficzna kultura i tradycja. I to na tym opierać się ma „ideologia praw człowieka”. Czy można ją jednak uznać za religię?

Czym jest w ogóle „religia obywatelska”? Termin we współczesnym rozumieniu związany jest z amerykańskim socjologiem Robertem N. Bellahem, który wprowadził go do ponownego użytku, zaczerpując od Jana Jakuba Rousseau (rozdział VIII „Umowy społecznej”) (Rousseau, 2010). Bellah definiuje to pojęcie jako „ten religijny wymiar, który [...] występuje w życiu każdego narodu, poprzez który interpretuje on swoje doświadczenia historyczne w świetle rzeczywistości transcendentnej” (1975, za: Burdziej, 2014, s. 530). Dla porównania współczesny polski badacz - Stanisław Burdziej definiuje religię obywatelską jako „zbiór przekonań zakładających transcendentny wymiar spraw politycznych, zawierający pewne elementy religii rozumianej tradycyjnie, spotykany zwłaszcza w społeczeństwach silnie zróżnicowanych etnicznie i wyznaniowo" (Burdziej 2014, s. 535). Dlaczego zdecydował się on na zawężenie zakresu znaczenia? Porównując religię obywatelską do innych form związków między religią a polityką, stwierdził, że na tle innych, podobnych zjawisk, wyróżnia ją: a) demokratyczny charakter wspólnoty politycznej, b) zasadniczo dobrowolny charakter, c) pluralizm wyznaniowy danej wspólnoty i d) obecność elementów religii rozumianej tradycyjnie. Warunki te winny być spełnione łącznie, w przeciwnym razie mamy prawdopodobnie do czynienia $\mathrm{z}$ inną formą związku polityki i religii. Przykładowo, zdaniem S. Burdzieja, komunizm nie był religią obywatelską (wbrew opinii wielu innych badaczy), gdyż nie ma odniesień do tradycyjnie rozumianej religii (Burdziej, 2014).

\section{CHRZEŚCIJAŃSKA GENEZA PRAW CZŁOWIEKA}

We współczesnym, zachodnim dyskursie politycznym, prawa człowieka funkcjonują obecnie na prawach oczywistości. Niezależnie od opcji politycznej, którą różne stronnictwa polityczne reprezentują, prawa człowieka - jako takie - nie są nigdy poddawane w wątpliwość. Mają one być substytutem religii w świecie zachodnim, stanowią główny punkt ciężkości dzisiejszej polityki. Mało tego - 
stały się wręcz niepodważalnym dogmatem. „I dlatego wydaje się dziś tak niestosowne, tak bluźniercze, tak skandaliczne krytykowanie ideologii praw człowieka jak to niegdyś było z wątpieniem w istnienie Boga" (Benoist, 2016, s. 15-16).

A. de Benoist postrzega jednak prawa człowieka nie jako uniwersalne, bezczasowe i niezbywalne prawa, obowiązujące bezwarunkowo, zawsze i wszędzie, ale jako ideologię, która narodziła się w określonym miejscu, w określonym czasie, w obrębie specyficznego kontekstu kulturowego. W taki właśnie sposób winny być one rozpatrywane i oceniane. Jak stwierdza francuski myśliciel, prawa człowieka są ahistoryczne, ale mają historię (Benoist, 2016, s. 32):

„Ideologia praw człowieka jest wytworem myśli oświeceniowej, [...] sama idea praw człowieka mieści się w specyficznym horyzoncie zachodniej nowoczesności. Narzuca się więc pytanie o to, czy ściśle ograniczone źródło tej ideologii nie zaprzecza roszczeniom do powszechności. Każda deklaracja praw jest umiejscowiona w czasie [...]. Porównując teorię praw człowieka $\mathrm{z}$ wszelkimi formami kultury zbiorowości ludzkich, oczywiste staje się, że jest ona w większym stopniu wyjątkiem niż regułą, a nawet stanowi wyjątek w obrębie samej kultury europejskiej, ponieważ pojawiła się w ściśle określonym, stosunkowo późnym momencie jej dziejów" (Benoist, 2018).

Istotna w tym cytacie jest nie tylko negacja powszechności praw człowieka, ale również podkreślenie tego, że nie można utożsamiać ich z kulturą europejską jako taką, jedynie z pewnym jej wycinkiem czasowym. Jak w takim razie widziano człowieka w czasach przednowoczesnych?

Autor Au-delà des droits de l'homme zwraca uwagę, że dla Greków starożytnych sprawiedliwość oznaczać miała właściwą proporcję, tj. odpowiednią proporcję w rozdziale dóbr i obowiązków (Benoist, 2016, s. 32). W Rzymie antycznym z kolei „»jus « praw klasycznego prawa rzymskiego miał na celu [...] "właściwy podział «, który winien istnieć pomiędzy ludźmi, odpowiednia część, która winna być przyznana każdemu" (Benoist, 2016).

Istotne jest w obu przypadkach to, że pojęcie sprawiedliwości i prawa oparte było nie tyle na samym człowieku-jednostce, ile na pewnej, proporcjonalnie ustrukturyzowanej sieci powiązań czy też stosunków społecznych, nakierowanych na dobro wspólne. Sprawiedliwość rozumiano jako właściwe proporcje między członkami społeczności, umożliwiające harmonię. Natura ludzka, choć była pewnym punktem odniesienia, miała jednak nie być postrzegana sama w sobie, całkowicie niezależnie od całości powiązań społecznych (Benoist, 2016, s. 33). Takie pojmowanie sprawiedliwości byłoby dla ówczesnych ludzi zupełnie pozbawione sensu. Prawo nie jest czymś, co przypisane jest do ode- 
rwanej jednostki, bytu niezależnego od konkretnego kontekstu społecznego, „człowieka w ogóle”. Starożytni Grecy pozbawieni byli idei jednostki abstrakcyjnej, będącej posiadaczem praw uniwersalnych i niezbywalnych, na mocy samego jej istnienia.

Zdaniem francuskiego myśliciela pierwsze „pęknięcie” pojawiło się wraz z chrześcijaństwem (Benoist, 2016). Religia chrześcijańska ogłosiła wyjątkowość każdego człowieka. Każdy bowiem posiada duszę, która znajduje się w bezpośrednim stosunku do Boga - człowiek staje się więc nosicielem wartości absolutnej, tj. wartości, która nie wynika z jego osobistych walorów czy cech, ani też z jego przynależności do specyficznej wspólnoty społecznej. Człowiek staje się wartością samą w sobie - chrześcijaństwo wytwarza więc „czysto indywidualną definicję wolności” (Benoist, 2016).

Poprzez te fundamentalne innowacje antropologiczne chrześcijaństwo zdaniem A. de Benoist - „wydrążyło rów między genezą człowieka (Bóg) i jego egzystencją doczesną" (Benoist, 2016, s. 34). Innymi słowy, nastąpiło wycofanie „ontologicznego zakotwiczenia” człowieka z jego egzystencji społecznej i przeniesienie na jego duszę. W efekcie, na poziomie metafizycznym, doprowadziło to do rozdziału jednostki i społeczeństwa - człowieka i obywatela. Nie znaczy to oczywiście, że od tej pory związki międzyludzkie przestają się w ogóle liczyć. Stają się jednak drugorzędne, gdyż współbycie ludzi nie sprowadza się jedynie do ich jestestwa (Benoist, 2016). Innymi słowy, chrześcijanin sam (a nie dobro wspólnoty) staje się ostatecznym celem politycznym, a jego osoba transcendować ma Państwo. „Obwieszczając metafizyczne ukierunkowanie człowieka, chrześcijaństwo dąży do odwrócenia ludzkiej sprawiedliwości od jej zwrócenia na świat zmysłowy" (Benoist, 2016, s. 35). Według A. de Benoist właśnie tutaj tkwi zarodek współczesnego pojmowania wolności jednostki, które to stać ma w opozycji do Państwa jako takiego. Tutaj właśnie widzi francuski autor zarodek przyszłych „praw człowieka” (Benoist, 2016, s. 34-35). Konkretniej rzecz ujmując, wiara w jedynego Boga umożliwia ujęcie wszystkich ludzi jako równych synów bożych - bez różnicy na pochodzenie. W chrześcijaństwie, przed byciem członkiem danego ludu, narodu czy kultury, człowiek jest pojmowany przede wszystkim jako jednostka w relacji do Boga. „Nie masz Żyda, ani Greka; nie masz niewolnika ani wolnego; nie masz mężczyzny i niewiasty; albowiem wszyscy wy jednym jesteście w Chrystusie Jezusie" (Gal 3:28, Biblia Gdańska).

„Religia praw człowieka, oparta o monohumanizm, zdaje się być powiązana [...] z egalitaryzmem z jednej strony, a z drugiej - z monoteizmem. Myśl biblijna jest monohumanistyczna i monogenistyczna »dlatego, że jest również monote- 
istyczna«. To jest obsesja Tego Samego [...]: wszyscy ludzie są tacy sami przed Jahwe" (Benoist, Faye, 1981).

Francuski autor stwierdza, że w większości kultur (włączając w to europejską) człowiek nigdy nie był pojmowany jako monada. Pojęcia porządku, sprawiedliwości i harmonii nie były wyprowadzane od jednostki, jej unikalnego miejsca w świecie, ale od grupy, tradycji, pokrewieństwa lub „całości rzeczywistości” (Benoist, 2016, s. 92). „W Europie antycznej »człowiek« nie istniał. Byli »ludzie«. Byli Grecy, Rzymianie, barbarzyńcy, patrycjusze, niewolnicy itd." (Benoist, Faye, 1981). Człowiek uniwersalny nie istnieje. Nie istnieje też uniwersalne prawo moralne dla wszystkich ludów, gdyż w pojęciu starożytnych nie było jedynego Boga, odpowiedzialnego za stworzenie wszystkich ludów. Grecy czcili bogów greckich, chrześcijanie zaś wierzą w jednego Boga, który nie jest bogiem tego, czy tamtego ludu, tylko całej ludzkości - bez różnicy na szerokość geograficzną czy specyfikę kulturową. Miejsce obywatelstwa bez uniwersalizmu (koncepcja wynaleziona przez dawnych Greków) zajmuje uniwersalizm bez obywatelstwa (Benoist, 2016, s. 36).W rezultacie, pojęcie „ludzkości” - samo w sobie - nabiera wagi moralnej. Wszyscy ludzie są tacy sami, skoro stworzeni przez tego samego Boga. Bóg stworzył ‘jednego’ człowieka na swoje podobieństwo (jedynego Boga). Jedność rodzaju ludzkiego jest odbiciem jedności Boga. Doktryna chrześcijańska obwieszcza jedność moralną całego gatunku ludzkiego, jednocześnie uważając jednostkę za byt nieredukowalny do wspólnoty politycznej. Konstytuuje się, w rezultacie, zupełnie nowy stosunek obywatela (chrześcijanina) do instytucji Państwa (Benoist, 2016).

Zdaniem A. de Benoist wiara w prawo naturalne ma się brać logicznie $\mathrm{z}$ afirmacji abstrakcyjnej „osoby ludzkiej”. Ma to być wiara w to, że znajduje się pewne prawo „w” człowieku, które jest jakoby wrodzone w jego naturę, i brać się ma z boskiej zasady, która manifestuje się w jego rozumie (Benoist, Faye, 1981).

„Ideologia praw człowieka to ideologia »naturalistyczna». Od Tomasza z Akwinu [...] do Claude'a Levi-Straussa [...] ideologia ta implikuje istnienie lub możliwość zaistnienia pewnego »stanu natury«, który społeczeństwo jest w stanie przywrócić (Rousseau) lub stworzyć (Locke). Ta wiara łączy w sobie klasyczne judeo-chrześcijaństwo, cechujące się wiarą w »naturalny porządek «, i nowoczesny racjonalizm, który dowodzi istnienia racji rzekomo »obiektywnych « i praw rzekomo "uniwersalnych «" (Benoist, Faye, 1981).

Jest jednak pewien problem, według francuskiego autora, w rozumieniu terminu „natura” czy „naturalny” w takim kontekście, gdyż pojęcia typu „porządek naturalny”, „natura ludzka”, „prawo naturalne” to ekwiwokacje. A. de Benoist 
zwraca uwagę na to, że np. termin „stan natury” zupełnie co innego oznacza w ustach Kalliklesa, Hobbesa czy Rousseau. Czy „stan natury” to stan pokoju czy stan wojny wszystkich ze wszystkimi, sprawiedliwości czy niesprawiedliwości itd.? Konsensusu na ten temat nie ma do dzisiaj. Francuz podkreśla, że człowiek, w rzeczywistości, nie posiada innej natury oprócz swojej kultury, dzięki której sam siebie kształtuje. „Człowiek istnieje jako człowiek jedynie w sposób »uformowany « poprzez instytucje i konstrukcje historyczne" (Benoist, Faye, 1981), a stan natury, poprzedzający wszelkie formy życia społecznego (zaludniony oderwanymi jednostkami), to, co najwyżej, racjonalna hipoteza (Benoist, 2016, s. 65).

W związku z wcześniej wspomnianą „rewolucją antropologiczną” chrześcijaństwa zmienia się też wartościowanie jednostki i wspólnoty. Jako że w chrześcijaństwie bycie człowiekiem, synem bożym (którego dusza jest w bezpośredniej relacji do Boga), jest traktowane jako pierwszorzędne, a bycie członkiem konkretnej wspólnoty politycznej jest drugorzędne - indywidualizm jest tego logiczną konsekwencją. Innymi słowy, indywidualizm wynika z monohumanizmu. „Jeśli istnieje »człowiek sam w sobie«, to przynależności lokalne, które odróżniają ludzi pomiędzy sobą, nie mają większego znaczenia" (Benoist, Faye, 1981).

Podsumowując, ideologia czy też religia praw człowieka - wg A. de Benoist opierać się ma na czterech „zasadach wiary”:

1. wiara w jedność rodzaju ludzkiego, oparta na wadze moralnej tego faktu;

2. wiara w istnienie pewnej „osoby ludzkiej”, niezależnej od specyficznych cech każdej, poszczególnej jednostki;

3. wiara w jedną "naturę ludzkąa, dająca podstawę pod "prawo naturalne”;

4. wiara w prymat jednostki nad wspólnotami organicznymi i historycznymi, którymi są kultury, ludy i narody (Benoist, Faye, 1981).

\section{KRYTYKA PRAW CZŁOWIEKA}

Podstawę dyskursu praw człowieka tworzy - zdaniem A. de Benoist - marzenie o ludzkości zjednoczonej tymi samymi normami moralnymi, żyjących pod jednym, uniwersalnym prawem (Benoist, 2016, s. 46). Oczywiście opiera się to na przyjętym implicite założeniu, że w gruncie rzeczy wszyscy ludzie są tacy sami. Czy są? „Kiedy mówi się o uniwersalności praw, jaki rodzaj uniwersalności ma się na myśli? Powszechność porządku geograficznego, filozoficznego czy moralnego?" (Benoist 2018). 
Jednym z zarzutów Francuza przeciw idei praw człowieka jest to, że nie mają one wcale charakteru uniwersalnego. Idea ta pojawiła się w określonym miejscu, w określonym czasie, w określonym kontekście kulturowym, a postulowana ich powszechność jest wytworem specyficznego Weltanschauung (zachodnia nowoczesność), który wytworzył specyficzną antropologię filozoficzną »człowieka samego w sobie«, która to - zdaniem A. de Benoist - jest bardziej wyjątkiem niż regułą na świecie. Przypisywanie takiej wizji człowieka całemu światu to nic innego jak projekcja. Postulowana ich oczywistość, niezbywalność i powszechność ma znacznie więcej wspólnego $\mathrm{z}$ wiarą religijną niż $\mathrm{z}$ faktami, gdyż nie ma ona żadnego, określonego fundamentu filozoficznego. Cytując samego A. de Benoist:

„Opierając się na twierdzeniach uznanych za »oczywiste« (»we hold these truths to be self-evident«, jakie znajdujemy w Deklaracji (niepodległości) amerykańskiej z lipca 1776), (prawa człowieka) prezentują się tak, jakby były nowym Dekalogiem [...]. Prawa człowieka mogą być więc zdefiniowane jako »religia ludzkości« [...]. Są one, jak pisze Régis Debray, »na chwilę obecną, ostatnią z naszych religii obywatelskich, duszą świata pozbawionego duszy - religią współczesnego Zachodu «" (Benoist, 2016, s. 14).

„Religia” praw człowieka ma - wg francuskiego autora - dzielić z chrześcijaństwem nie tylko uniwersalizm, ale również prozelityzm (a pewnym sensie nawet etnocentryzm). Kraje Zachodu pragną ją narzucać całemu światu - czy tego chce, czy nie. Albo prawa człowieka mają charakter uniwersalny - i wtedy należy to jednoznacznie wykazać, albo nie mają charakteru uniwersalnego w takim wypadku są one narzędziem Zachodu, służącym do walki ideologicznej i dominacji symbolicznej. Z tego właśnie względu uniwersalizacja praw człowieka wydaje się niczym więcej jak ciągiem dalszym zachodniego „syndromu kolonialnego" (Benoist, 2016, s. 91). W oczach francuskiego myśliciela ideologia praw człowieka jest współczesnym sposobem na podział świata na „cywilizowanych” i „barbarzyńców”. Tym drugim, z racji swojego „braku ucywilizowania”, można odmawiać prawa do samostanowienia, a w najgorszym wypadku - nawet człowieczeństwa, gdyż „nie wiedzą, co czynią”. W związku z tym może pojawić się pokusa do przyniesienia im „dobrej nowiny” - czy tego chcą, czy nie. Innymi słowy, prawa człowieka zdają się być zakamuflowaną formą zachodniego imperializmu. Modus operandi - analogiczny do dawnych konkwistadorów (chrześcijan).

Kolejnym zarzutem francuskiego myśliciela jest to, że „teoria praw człowieka wydaje się być w niewielkim stopniu skłonna do uznania różnorodności kulturowej i to z dwóch przyczyn: po pierwsze, z powodu zasadniczego indywidualizmu 
i wysoko abstrakcyjnego charakteru podmiotu, któremu przyznaje prawa; po drugie, z powodu swych silnych związków z kulturą zachodnią [...]. Wszelki uniwersalizm zmierza w kierunku zacierania różnic" (Benoist, 2018).

Problematyczność tego aspektu zauważyć możemy w przypadku, gdy mamy do czynienia $\mathrm{z}$ obyczajem kulturowym, potępianym z punktu widzenia ideologii praw człowieka, który cieszy się uznaniem wśród rdzennej populacji danego kraju. Klasycznym tego przykładem jest obrzezanie dziewczynek w niektórych państwach Czarnej Afryki. Nieobrzezana kobieta nie znajdzie męża i nie będzie mogła mieć dzieci, i dlatego kobiety, które same zostały obrzezane, będą pierwszymi w kolejności osobami chętnymi do tego, by obrzezać własne córki (Benoist, 2016, s. 95). Przy założeniu, że obyczaj ten oceniany jest jako „barbarzyński” z punktu widzenia praw człowieka, A. de Benoist stawia pytanie: $w$ imię czego można by zabronić obyczaju, który nie jest narzucany z zewnątrz? Skoro „moja” wolność winna nie wkraczać w wolność innych, na jakiej podstawie zakazywać coś innym ludziom?

Postulowanie uniwersalnej powszechności ideologii praw człowieka opiera się na milcząco przyjętym założeniu, że (co najmniej) większość ludów świata podąża drogą rozwoju od wspólnoty mitycznej do „nowoczesnej” - analogicznie do zindustrializowanych narodów zachodnich. To, rozpowszechnione na Zachodzie, przekonanie ma działać na zasadzie samospełniającej się przepowiedni zachodnia teoria modernizacji ma być narzucana krajom niezachodnim. I to ma właśnie być „koniem trojańskim Zachodu” (Benoist, 2016, s. 96).

„Akceptacja różnorodności kulturowej wymaga pełnego uznania Innego. Ale jak uznać Innego, jeśli jego wartości i praktyki sprzeciwiają się tym, które chcielibyśmy zaszczepić? [...] Ale w jaki sposób pogodzić prawa człowieka z wielością systemów kulturowych i wierzeń religijnych? Jeżeli szacunek do praw jednostki wiedzie przez brak szacunku do kultur i ludów, czy należy więc skonkludować, że wszyscy ludzie są równi, ale kultury przez owych równych stworzone nie są równe?” (Benoist, 2016, s. 96-97).

\section{ZAKOŃCZENIE}

W istocie A. de Benoist zmierza ostatecznie do tego, aby wykazać, że „drugim dnem” ideologii praw człowieka jest 1) implicytne poczucie wyższości Zachodu nad innymi kulturami, i 2) pragnienie Zachodu, by cały świat „nawrócić” na religię praw człowieka i - tym samym - zapanować nad nim symbolicznie 
i ideologicznie. Ponadto francuski myśliciel uważa, że istnieje synergia między ideologią praw człowieka a globalnym kapitalizmem, tj. ma ona być de facto ideologiczną podbudową globalnego kapitalizmu. Dzieje się tak, gdyż „system rynkowy może się, tak naprawdę, rozprzestrzenić jedynie w społeczeństwach, gdzie jednostki są już zatomizowane" (Benoist, 2016, s. 31). Ideologia praw człowieka nadawać się ma do tego idealnie, bowiem jej efektem (zamierzonym lub nie) ma być, ostatecznie, atomizacja społeczna spowodowana dezintegracją holistycznych kultur, dzięki konstytutywnej dla niej absolutyzacji jednostki $\mathrm{i}$ „utowarowieniu” relacji społecznych.

Ponadto mimo oficjalnej równości wobec prawa wszystkich obywateli, zawartej w ideologii praw człowieka, teoretyczna równość wobec prawa pracodawcy i pracownika w żaden sposób nie zapobiega sytuacji, w której pierwszy wyzyskuje drugiego. Francuski autor porównuje to do sytuacji, w której zrównano by prawa wilka i owcy. Innymi słowy, „frazeologia praw człowieka jest niczym więcej jak transfiguracją ideologiczną form prawnych stosunku handlowego, który sam jest sposobem działania kapitalistycznej eksploatacji” (Benoist, 2016, s. 29).

Co więc proponuje A. de Benoist? Przede wszystkim nie sądzi, by związane z prawami człowieka „odpolitycznienie” było właściwym sposobem na rozwiązanie problemu wolności jednostki i jej praw. Jasno podkreśla, iż kontestacja ideologii praw człowieka to nie kontestacja tego, że człowiek ma prawa. Nie jest to również pochwała despotyzmu czy autorytaryzmu. Jedyne, co kontestuje, to to, że - jego zdaniem - ideologia praw człowieka jest do tego optymalnym środkiem. Potwierdza on, że wolność jest wartością podstawową, tyle tylko, że winna ona być oparta nie na podstawach prawa czy moralności. Jest ona bowiem przede wszystkim kwestią polityczną. I winna być rozwiązana politycznie.

Władza polityczna winna być zrównoważona nie dlatego, że jednostki cieszą się niezbywalnymi prawami, ale dlatego, że wspólnota polityczna, w której rządzi despotyzm lub absolutyzm, jest złą wspólnotą polityczną. Innymi słowy, autorytet polityczny winien szanować wolność obywateli nie dlatego, że „mają do tego prawo", tylko dlatego, że takie społeczeństwo jest po prostu politycznie lepsze (Benoist, 2016, s. 152). Wiąże się z tym, postulowana przez niego, rehabilitacja pojęcia „przynależności” (do konkretnej wspólnoty politycznej), bez której „wolność, równość i sprawiedliwość są wyłącznie nieskutecznymi abstrakcjami” (Benoist, 2016). W związku z tym, aby prawa obywatelskie miały realne ugruntowanie, należy w polityczności i obywatelstwie widzieć nie coś drugorzędnego (wynikłego z abstrakcyjnych „praw”), tylko pierwotny warunek, umożliwiający optymalne „życie-razem” (Benoist, 2016, s. 153). 
Krytyka praw człowieka dokonana przez A. de Benoist bez wątpienia budzić będzie wiele kontrowersji. Wykazuje on celnie słabości idei praw człowieka, m.in. brak jasnej podstawy filozoficznej czy wątpliwą uniwersalność. Rodzi się jednak pytanie: jeśli nie prawa człowieka - to co? Najlepsza nawet krytyka bowiem nie wystarczy.

Jeśli zrezygnujemy z pojęcia godności ludzkiej, przynależącej wszystkim i będącej podstawą praw, to na jakiej płaszczyźnie budować prawo międzynarodowe? Jeśli przyjąć, że każda kultura ma swoje standardy, swoje prawodawstwo itd., to w jaki sposób przezwyciężyć relatywizm w celu porozumienia międzynarodowego? Francuski autor nie daje żadnej odpowiedzi.

Wypada również wspomnieć pewien mankament metodologiczny. Autor Au-delà des droits de l'homme używa zamiennie terminów „religia praw człowieka” i ,ideologia praw człowieka”. Nie można jednak terminów „religia” i „ideologia” w żadnym wypadku utożsamiać. Są to jednak zdecydowanie różne pojęcia i należałoby to uwzględnić.

Pozostaje jeszcze kwestia stanowiska Kościoła katolickiego do praw człowieka - nie jest ona bowiem jednoznaczna. Przynajmniej niektóre $\mathrm{z}$ aspektów teorii prawno-człowieczej były przez Kościół kwestionowane. Przykładem tego jest breve papieża Piusa VI, wydane 10 lutego 1791, w której krytycznie oceniał niektóre z artykułów Deklaracji Praw Człowieka i Obywatela, dotyczące zwłaszcza kwestii wolności religijnej i prawa własności (Dudziak, 2007, s. 379). Ten sam papież wydał potem encyklikę Adeo nota, z 23 kwietnia 1791, w której utrzymywał, że Deklaracja Praw Człowieka i Obywatela skierowana jest przeciwko społeczeństwu i religii. W XIX w. papieże potępiali Deklarację, gdyż postrzegali ją jako drogę do emancypacji człowieka bez przewodniej roli Kościoła (L’Osservatore Romano, 2018). Mimo że stosunek Kościoła do praw człowieka zmienił się w ciągu lat, to jednak trzeba mieć na uwadze to, że w ciągu lat zmianom (rozszerzeniom) podlegały również same prawa człowieka - przykładem chociażby tzw. prawa reprodukcyjne, w tym prawo do aborcji. Oczywiste jest to, że Kościół widzieć będzie w tym pogwałcenie prawa do życia, gdyż stoi on konsekwentnie na stanowisku, że o człowieczeństwie mowa jest od poczęcia do naturalnej śmierci.

Co ciekawe, papież Franciszek w przemówieniu do członków Korpusu Dyplomatycznego akredytowanego przy Stolicy Apostolskiej - podkreślając wagę praw człowieka - wspomniał, że w następstwie rewolucji obyczajowej z maja 1968 r. pewne prawa człowieka uległy stopniowej modyfikacji (Stopka, 2018). Inne, „,nowe prawa”, zostały dodane, nierzadko sprzeczne z poprzednimi, jak również nieraz sprzeczne z kulturą wielu krajów, które z tego powodu „nie 
odczuwają poszanowania dla swoich tradycji społeczno-kulturowych, a czują się raczej pominięte w obliczu rzeczywistych potrzeb, jakim muszą stawić czoło" (Franciszek, 2018). Franciszek wnioskuje, że - paradoksalnie - hipertrofia praw człowieka może prowadzić do nowoczesnych form kolonizacji ideologicznej bogatych i silnych państw kosztem najbiedniejszych i najsłabszych. Wydaje się to frapujące, mając na uwadze, że A. de Benoist dochodzi do bardzo podobnych wniosków, wychodząc z zupełnie przeciwstawnych założeń ideologicznych.

Podsumowując, zdaje się jednak, że francuski autor ma - zasadniczo - rację w swej głównej tezie, gdyż mimo początkowej „konsternacji” Kościoła kolejni papieże w coraz większym stopniu zaczęli uznawać prymat idei praw człowieka i włączać ją w głównonurtowy katolicyzm. Warto pamiętać, że to papieże zaczęli czuć się w obowiązku włączania idei „apostołów” praw człowieka do swojej doktryny, a nie na odwrót. Co to mówi o tym, która religia dominuje w świecie zachodnim?

\section{BibLIOGRAFIA:}

Bellah, R. (1975). The Broken Covenant: American Civil Religion in Time of Trial. Nowy Jork: The Seabury Press.

Benoist, A. de (2016). Au-delà des droits de l'homme: pour défendre les libertés. Paris: Pierre-Guillaume de Roux.

Benoist, A. de (2018). Etnobójcza ideologia Zachodu. Prawa człowieka i prawa narodów. Pobrane z: http://www.nacjonalista.pl/2012/07/26/alain-de-benoist-etnobojczaideologia-zachodu-prawa-czlowieka-i-prawa-narodow/.

Benoist, A. de, Faye, G. (1981). La religion des droits de l'homme. Éléments pour la civilisation européenne, 37, 5-21.

Burdziej, S. (2014). Religia obywatelska. W: P. Burgoński, M. Gierycz (red.). Religia i polityka. Zarys problematyki (s. 530-544). Warszawa: Dom Wydawniczy ELIPSA.

Dudziak, E. (2007). Kościół Katolicki wobec praw człowieka. Ewolucja stanowiska. Studia $z$ Prawa Wyznaniowego, 10 (2007), 375-405.

Franciszek (2018). Franciszek przypomniat światu o znaczeniu praw człowieka [Dokumentacja]. Pobrane z: https://www.deon.pl/religia/serwis-papieski/dokumenty/ przemowienia-papieskie/art,214,franciszek-przypomnial-swiatu-o-znaczeniupraw-czlowieka-dokumentacja.html.

L'Osservatore Romano (2018). Kościół a prawa człowieka. Pobrane z: http://www. osservatoreromano.va/pl/news/koscio-a-prawa-czowieka.

Rousseau, J.J. (2010). Umowa społeczna. List o widowiskach. Warszawa: PWN.

Taguieff, P. A. (1994). Sur la Nouvelle droite. Paryż: Descartes \& Cie.

Stopka, A. (2018). Prawa człowieka według Kościoła. Pobrane z: https://pl.aleteia. org/2018/06/01/prawa-czlowieka-wedlug-kosciola/. 